
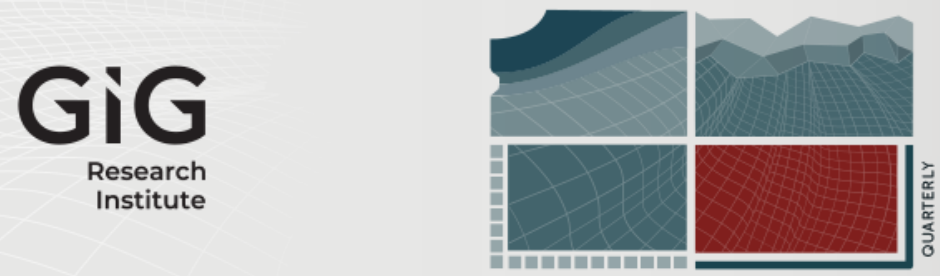

JOURNAL

OF

SUSTAINABLE

MINING

\title{
Ammonia-Ca-K competitive ion-exchange on zeolites in mining wastewater treatment: batch regeneration and column performance
}

Author(s) ORCID Identifier:

Roberto Martín Narbaitz (iD) 0000-0001-8874-4132

Majid Sartaj (iD 0000-0001-6482-9377

Follow this and additional works at: https://jsm.gig.eu/journal-of-sustainable-mining

Part of the Explosives Engineering Commons, Oil, Gas, and Energy Commons, and the Sustainability Commons

\section{Recommended Citation}

Narbaitz, Roberto Martín; Chartrand, Zachary G.; Sartaj, Majid; and Downey, Jason (2020) "Ammonia-Ca-K competitive ion-exchange on zeolites in mining wastewater treatment: batch regeneration and column performance," Journal of Sustainable Mining: Vol. 19 : Iss. 2 , Article 1.

Available at: https://doi.org/10.46873/2300-3960.1006

This Research Article is brought to you for free and open access by Journal of Sustainable Mining. It has been accepted for inclusion in Journal of Sustainable Mining by an authorized editor of Journal of Sustainable Mining. 


\title{
Ammonia-Ca-K competitive ion-exchange on zeolites in mining wastewater treatment: batch regeneration and column performance
}

\begin{abstract}
This manuscript addresses the treatment explosives-impacted mining wastewaters (EIMWW) using ionexchange to remove elevated levels of ammonia. Repeated batch loading-regeneration cycles were conducted for two commercially available zeolite media used in the treatment of ammonia-ladenEIMWW to establish the effects of competing ions and regeneration solution composition. The Northern Ontario EIMWW tested contained $3.87 \mathrm{meq} / \mathrm{L}$ total ammonia (TA) as well as $2.85 \mathrm{meq} / \mathrm{L} \mathrm{Kp}$ and $3.9 \mathrm{meq} / \mathrm{L}$ $\mathrm{Ca} 2 \mathrm{p}$.The media studied were a natural clinoptilolite and a modified clinoptilolite (SIR-600). Five regenerant solutions with different $\mathrm{NaCl}$ and $\mathrm{KCl}$ concentrations were evaluated. The presence of potassium in the regenerant was found to hinder the TA exchange capacity of both zeolites. The SIR-600 and the natural clinoptilolite used in conjunction with the $10 \% \mathrm{NaCl}$ solution featured the best TA exchange capacities, $0.46 \pm 0.02 \mathrm{meq} \mathrm{TA} / \mathrm{g}$ and $0.36 \pm 0.05 \mathrm{meq} \mathrm{TA} / \mathrm{g}$, respectively. The batch tests showed that both media had a slight preference for Kp over TA. The continuous flow column tests performed using SIR- 600 media greatly accentuated the selectivity of Kp over TA. In reaching the same 0.55 meq TA/L breakthrough level, the same modified zeolite column was able to treat five time more volume of a synthetic TA solution than EIMWW.
\end{abstract}

\section{Keywords}

Ion exchange; Ammonia; Clinoptilolite; Mining wastewater; Competitive ion exchange; Potassium

\section{Creative Commons License}

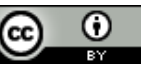

This work is licensed under a Creative Commons Attribution 4.0 License. 


\title{
Ammonia-Ca-K Competitive Ion-Exchange on Zeolites in Mining Wastewater Treatment: Batch Regeneration and Column Performance
}

\author{
Zachary G. Chartrand ${ }^{a}$, Roberto M. Narbaitz ${ }^{a, *}$, Majid Sartaj ${ }^{a}$, Jason Downey ${ }^{b}$ \\ ${ }^{a}$ Department of Civil Engineering, University of Ottawa, 161 Louis Pasteur Pvt., Ottawa, Ontario, K1N 6N5, Canada \\ ${ }^{\mathrm{b}}$ Dowclear Inc, 627 South Island Park Drive, Manotick, Ontario, K4M 1J2, Canada
}

\begin{abstract}
This manuscript addresses the treatment of explosives-impacted mining wastewaters (EIMWW) using ion-exchange to remove elevated levels of ammonia. Repeated batch loading-regeneration cycles were conducted for two commercially available zeolite media used in the treatment of ammonia-laden EIMWW to establish the effects of competing ions and regeneration solution composition. The Northern Ontario EIMWW tested contained 3.87 meq/L total ammonia (TA) as well as $2.85 \mathrm{mg} / \mathrm{L} \mathrm{K}^{+}$and $3.9 \mathrm{meq} / \mathrm{L} \mathrm{Ca}^{2+}$. The media studied were a natural clinoptilolite and a modified clinoptilolite (SIR-600). Five regenerant solutions with different $\mathrm{NaCl}$ and $\mathrm{KCl}$ concentrations were evaluated using batch tests. The presence of potassium in the regenerant was found to hinder the TA exchange capacity of both zeolites. The SIR-600 and the natural clinoptilolite used in conjunction with the $10 \% \mathrm{NaCl}$ solution featured the best TA exchange capacities, $0.46 \pm 0.02 \mathrm{meq}$ TA/g and $0.36 \pm 0.05 \mathrm{meq} \mathrm{TA} / \mathrm{g}$, respectively. The batch tests showed that both media had a slight preference for $\mathrm{K}^{+}$over TA. The continuous flow column tests performed using SIR-600 media greatly accentuated the selectivity of $\mathrm{K}^{+}$over TA. In reaching the same $0.55 \mathrm{meq}$ TA/L breakthrough level, the same modified zeolite column was able to treat five times more volume of a synthetic TA solution than EIMWW.
\end{abstract}

Keywords: ion exchange, ammonia, clinoptilolite, mining wastewater, competitive ion exchange, potassium

\section{Introduction}

$\mathrm{T}$ he mining industry extensively uses nitrogen-based explosives, with ammonium nitrate mixed with fuel oil (ANFO) being the primary blasting agent. Cyanide destruction, transformation of amines in flotation circuits, $\mathrm{pH}$ regulation agents, ammonium sulphate as eluent of uranium from ion exchange resins, ammonium hydroxide used in uranium precipitation, and ammonia used to recover copper and nickel in hydrometallurgical processes are other sources of ammonia in mining water [1-4]. These result in mining effluents containing elevated concentrations of ammonia. Ammonia discharges can be toxic to fish and can result in substantially lower dissolved oxygen levels in receiving waters that also greatly impact aquatic life. Accordingly there are an increasing number of ammonia discharge regulations around the world to curb the discharge of ammonia into the environment [5-8]. This has led to the research and development of multiple treatment options for the removal and/or transformation of ammonia, while aiming to minimize subsequent environmental consequences. Biological nitrificationdenitrification, which is quite common in domestic wastewater treatment, is not the best choice for mining wastewater treatment because it is significantly impacted by low temperatures, it does not perform as well when there are large fluctuation in the influent ammonia

Received 18 October 2019; revised 5 February 2020; accepted 23 February 2020.

Available online 5 October 2020.

* Corresponding author.

E-mail addresses: zchar071@uottawa.ca (Z.G. Chartrand), narbaitz@uottawa.ca (R.M. Narbaitz), msartaj@uottawa.ca (M. Sartaj), jdowney@dowclear.com (J. Downey). 
concentrations, and it is impacted by ammonia toxicity $[6,9-11]$. These conditions make physicochemical treatment methods particularly suitable, ammonia removal has been achieved through adsorption/ion-exchange, air stripping, microwave radiation, reverse osmosis, sonification, and chemical processes such as chemical precipitation or breakpoint chlorination $[6,7,9,10,12-17]$. Air stripping, which may be economical in warm climates, is not efficient in the cold temperatures encountered in Northern Canadian mines. This is because under normal conditions most of the ammonia is present as ammonium $\left(\mathrm{NH}_{4}^{+}\right)$, at low temperatures an even smaller fraction of the total ammonia (TA) is present in the strippable $\mathrm{NH}_{3}$ form, and the mass transfer of $\mathrm{NH}_{3}$ is slower at these very low temperatures. It also requires chemicals to raise the $\mathrm{pH}$ but their transportation costs are high due to the remoteness of these mine sites. On the other hand, ion exchange removes the ionized form of ammonia $\left(\mathrm{NH}_{4}^{+}\right)$so it is naturally favored for cold weather applications.

Among the physicochemical methods, ion exchange (IE) is a good candidate for the removal of ammonia from explosives-impacted mining wastewaters (EIMWW). IE is an effective technology because at near neutral $\mathrm{pH}$ conditions ammonia is primarily present as ammonium $\left(\mathrm{NH}_{4}^{+}\right)$ions [5]. It also offers the advantages of fast start-up times, lowcost, simplicity of application and operation.

Removal of ammonia by IE, particularly zeolites due to their high affinity for ammonia and low cost, is a well-documented process $[7,14,15,17-22]$. Ames proposed the following general order of selectivity for clinoptilolite, a common zeolite [23]:

$$
\begin{aligned}
& \mathrm{Cs}^{+}>\mathrm{Rb}^{+}>\mathrm{K}^{+}>\mathrm{NH}_{4}^{+}>\mathrm{Ba}^{2+}>\mathrm{Sr}^{2+}>\mathrm{Na}^{+}>\mathrm{Ca}^{2+}> \\
& \mathrm{Fe}^{2+}>\mathrm{Al}^{3+}>\mathrm{Mg}^{2+}>\mathrm{Li}^{+}
\end{aligned}
$$

This order of selectivity has been studied and confirmed by numerous studies [20,24]. It should be noted that the majority of the $\mathrm{NH}_{4}^{+}$-IE literature deals with the IE treatment of synthetic and/or single solute ammonia solutions rather than real wastewaters that contain numerous other ions. In addition, the ammonia exchange capacities reported in the literature vary widely in part due to the many differences amongst different zeolite types, the differences among the solutions being treated, and operational conditions such as $\mathrm{pH}$ and temperature [17-19,22].
A literature search did not identify studies on the IE treatment of this type of explosives impacted wastewater. A critical characteristic for the IE treatment of this type of wastewater is that it has significant concentration of ammonia in addition to other ions, such as $\mathrm{Ca}^{2+}$ and $\mathrm{K}^{+}$. As zeolites generally have a slightly higher selectivity for $\mathrm{K}^{+}$than $\mathrm{NH}_{4}^{+}$, the treatment of multi-solute solutions has often resulted in lower $\mathrm{NH}_{4}^{+}$removals than those reported for single solute ammonia solutions due to the competition for exchange sites $[17,20,21,25]$. However, one study reported the effect of the other cations upon uptake of ammonium ion being relatively small [7]. According to [26] the simultaneous uptake and elution behaviour of $\mathrm{NH}_{4}^{+}$and $\mathrm{K}^{+}$on clinoptilolite are poorly documented.

The overall objective of this study was to evaluate the effectiveness of two IE media in the removal of TA from a real EIMWW. The specific objectives of this study were: a) to study the effects of regeneration solution composition on the removal of ammonia from EIMWW using a natural clinoptilolite and a modified clinoptilolite using batch tests, and b) to study the competitive ion exchange within a continuous flow column, which is the more common IE treatment system configuration. Competitive ion exchange is believed to be a significant factor on the feasibility of an IE system for treating EIMWW. The majority of studies have focused on the conventional sodium or acid-based regenerations, but it is believed that the selectivity order can be partially circumvented by greatly increasing the concentration of a less preferred ion [14]. Accordingly, this study will evaluate the impact of using both sodium and potassium regeneration solutions.

\section{Experimental Methods and Materials}

The experimental plan consisted of performing batch and continuous flow column experiments using real EIMWW in an attempt to assess the performance of an IE process, and to establish the effects of ionic competition. A key objective of the batch experiments was to identify the most suitable regenerant among several combinations of $\mathrm{NaCl}$ and $\mathrm{KCl}$ solutions. The column experiments used the best regeneration solution identified during the batch tests.

\subsection{Materials}

The EIMWW was collected from a blasting operation in a Northern Ontario mine, and filtered in the lab prior to the testing. For simplicity, the ammonia concentrations will be quantified in terms of total 
ammonia (TA) as the sum of ammonium ion $\left(\mathrm{NH}_{4}^{+}\right)$ and unionized ammonia $\left(\mathrm{NH}_{3}\right)$. The EIMWW contained approximately $3.87 \mathrm{meq}$ TA/L $(70 \mathrm{mg}$ TA as $\mathrm{NH}_{4}^{+} / \mathrm{L}$ ) and a complex blend of dissolved metals and anions. Full chemical analysis was accomplished via Inductively Coupled-Plasma (ICP) analysis. TA, potassium and calcium were determined to be the major three cations in EIMWW that are most relevant based on the clinoptilolite selectivity, therefore their interactions were the central focus of the study. For comparison of the impact of competition among ions, one column test was performed with a single-solute synthetic wastewater feed, which was prepared by dissolving technical grade $\left(\mathrm{NH}_{4}\right)_{2} \mathrm{SO}_{4}$ (Fisher Sci., Fair Lawn, NJ) in distilled water $(230 \mathrm{mg}$ in $1 \mathrm{~L})$ for the desired concentration of approximately $3.87 \mathrm{meq} \mathrm{TA} / \mathrm{L}$.

The two IE materials considered were both zeolitic in nature. Clinoptilolite is inexpensive and known for its molecular sieving abilities as well as its high affinity for ammonia [14,27]. A natural zeolite (mineral clinoptilolite) was obtained from The Seed Supply co. (Saint Anthony, ID). According to the manufacturer, this product was $85 \%$ clinoptilolite with a cation exchange capacity of $1.4-1.65 \mathrm{meq} / \mathrm{g}$ and a maximum water retention of $55 \%$ of its weight. The bulk density was approximately 881$961 \mathrm{~kg} / \mathrm{m}^{3}$ [28]. The rock elemental composition was reported by the supplier [28], it consisted primarily of $\mathrm{SiO}_{2}(67.4 \%), \mathrm{Al}_{2} \mathrm{O}_{3}(10.6 \%), \mathrm{K}_{2} \mathrm{O}(4.19 \%), \mathrm{CaO}$ $(2.23 \%)$ and $\mathrm{Fe}_{2} \mathrm{O}_{3}(1.7 \%)$. The material had a surface area of $24.2 \mathrm{~m}^{2} / \mathrm{g}$, based on Brunauer-Emmet-Teller (BET) analysis at the Chemistry Department, University of Ottawa. The second IE material studied was a modified clinoptilolite (SIR-600, Resintech, West Berlin, NJ, USA). This modified clinoptilolite is typically utilized in the removal of cesium and ammonia from wastewaters [29]. Both materials were dried in an oven at $55{ }^{\circ} \mathrm{C}$ to remove excess moisture and cooled in desiccators. SIR-600 and the clinoptilolite were selected for this study because an earlier work showed that they had better TA removals from the same EIMWW than three different synthetic ion exchange media tested [30].

The purpose of the regenerations studies was to establish the best regeneration solution for the subsequent continuous flow column tests. The regeneration solutions were prepared using analytical grade $\mathrm{KCl}$ and $\mathrm{NaCl}(\mathrm{BDH}$, Mississauga, Canada). The ion exchange media was washed prior to use, but not preconditioned.

\subsection{Analytical Methods}

TA measurements were accomplished by nesslerization as per Standard Method $4500-\mathrm{NH}_{3}$ [31] and a spectrophotometer (DR6000, HACH, Loveland, $\mathrm{CO}$, USA). $\mathrm{pH}$ was recorded on a $\mathrm{pH}$ probe (PHC201, HACH, Loveland, CO, USA) and electrical conductivity (EC) was measured with a probe (40PCID, VWR, Radnor, PA, USA) and a benchtop meter.

Potassium and calcium concentrations were measured by direct air-acetylene flame atomic absorption (AA) spectroscopy as per Standard Methods 3111B [31] with an AA spectrometer (PinAAcle 55, PerkinElmer, Waltham, MA, USA).

\subsection{Experimental Setup}

\subsubsection{Batch regeneration study}

This study consisted of several cycles of the sequential batch loading of the exchange media with EIMWW, separation of the media through vacuum filtration, batch regeneration of the media using different regenerants, separation of the media from the regenerant and finally reloading of the regenerated media with EIMWW. A schematic of the steps performed during the loading experiments is presented in Fig. 1.

For the loading, $0.5 \mathrm{~g}$ of dry IE media (natural or modified SIR-600 zeolite) were place in $125 \mathrm{~mL}$ glass bottles which were filled with the EIMWW until the solution was overflowing, to avoid any head space and TA volatilization. Teflon tape was wrapped twice around the threaded portion of the $125 \mathrm{ml}$ glass bottles prior to filling; after filling, they were sealed with a Teflon lined cap and electrical tape wrapped around the cap to prevent loosening. Once sealed, the bottles were placed in an end-over-end tumbler that rotated the bottles at $10 \mathrm{rpm}$ to ensure gentle mixing and thorough solid-liquid contact, thus promoting IE. Preliminary batch experiments showed that equilibrium was reached in approximately $2 \mathrm{hrs}$; to be conservative and to simplify the logistics a 24 hour loading period was utilized. The bottles were then removed from the tumbler, and the content vacuum filtered through a glass microfiber filter (Whatman plc, Maidstone, Kent, England) to separate the solid and liquid phases. The filtrate was analyzed following the procedures cited above. The IE materials captured in the filtration were rinsed with distilled water and stored within 
a desiccator until they were regenerated. A mass balance between the initial and final conditions of the loading step was used to determine the equilibrium solid phase concentrations (or loadings or capacity) of TA, potassium and calcium. The equation is as follows:

$\mathrm{q}_{\mathrm{eq}}=\left(\mathrm{C}_{\mathrm{i}}-\mathrm{C}_{\mathrm{eq}}\right) \mathrm{V} / \mathrm{M}$

where $\mathrm{q}_{\mathrm{eq}}$ is the equilibrium IE material capacity (meq ion/g IE media); $\mathrm{C}_{\mathrm{eq}}$ and $\mathrm{C}_{\mathrm{i}}$ are the equilibrium and initial pollutant liquid phase concentrations, respectively $(\mathrm{meq} / \mathrm{L}) ; \mathrm{V}$ is the volume of solution (L) within the bottles and $\mathrm{M}$ is the mass of IE material (g). All batch experiments were performed in triplicate at room temperature (approximately $23{ }^{\circ} \mathrm{C}$ ).

In the regeneration step, illustrated by Fig. 2, the loaded IE media from each bottle was transferred to a new, clean $125 \mathrm{~mL}$ bottle; these bottles were then filled with the regeneration solution and sealed as described above. As desorption is a slower process, the regeneration contact time in the end-over-end tumbler was $48 \mathrm{hrs}$. Finally, the bottle contents were vacuum filtered to recover the IE media.

The five regeneration solutions evaluated were identified by their $\mathrm{Na}$ and $\mathrm{K}$ percentage by weight ratio. Only two contained potassium; a $5 \% \mathrm{KCl}$ solution, and a solution of $5 \% \mathrm{KCl}$ plus $5 \% \mathrm{NaCl}$. The sodium-based regeneration solutions consisted of $2.5 \%, 5$ and $10 \% \mathrm{NaCl}$ solutions. All results were referred to by the ion-exchanger regenerating salt $(\mathrm{NaCl}$ or $\mathrm{KCl})$ and their percent concentration. The exception being the $5 \% \mathrm{NaCl}+5 \% \mathrm{KCl}$ regenerations which were simply referred to as the $\mathrm{NaCl}+\mathrm{KCl}$. The $\mathrm{pH}$ of each batch regeneration solution was increased to approximately 10 by titration using $0.2 \mathrm{M} \mathrm{NaOH}$ or $0.2 \mathrm{M} \mathrm{KOH}$ solutions. Any $\mathrm{pH}$ adjustments for the $\mathrm{NaCl}+\mathrm{KCl}$ solution were accomplished prior to combining respective $\mathrm{K}$ and $\mathrm{Na}$ regenerants. The purpose of the potassium centric regenerations was to assess the impact of other regeneration solutions on the TA removal. The preloading with $\mathrm{K}$ may help predict the longterm performance of IE systems in the treatment of EIMWW, as it is analogous to the continuous exposure to $\mathrm{K}$. Once regenerated, the ion exchange media was reloaded following the same procedure as the original loading step. This study regenerated the ion exchange materials using $\mathrm{NaCl}$ solutions as this is the standard approach. This approach was selected because the study is primarily focused in determining the feasibility of the ammonia removal. It is recognized that to make the regeneration more sustainable the $\mathrm{NaCl}$ solutions should be recyclable, and there is a need for further investigation on this topic.

\subsubsection{Column experiments}

The second set of experiments investigated the competitive ion exchange in the practical column set-up, three column runs were performed. The experimental set-up is shown in Fig. 3, it included a $28.75 \mathrm{~mm}$ I.D., $150 \mathrm{~mm}$ long acrylic column. A total of $40 \mathrm{~g}$ of SIR- 600 was placed within the column. The SIR-600 media was selected for the column experiments because it had a higher TA uptake capacity than clinoptilolite in the batch loading tests, as well as a lower $\mathrm{Ca}^{2+}$ uptake capacity. To prevent loss of material, glass wool was inserted into the bottom of the column, a perforated acrylic disk was placed overtop the glass wool, and the IE media was placed

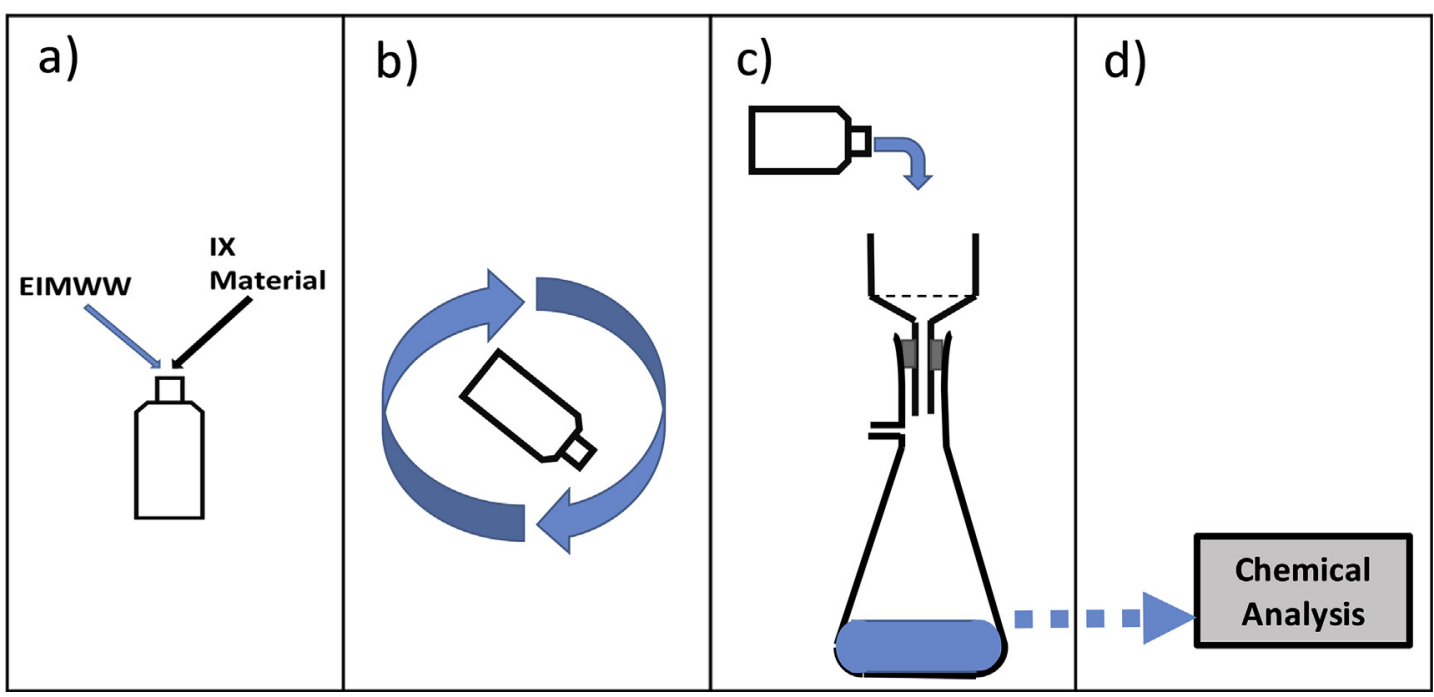

Fig. 1. Schematic of the Batch Loading Experiments (a) Bottle preparation; b) 24 hr equilibration while mixing in tumbler; c) Separation by vacuum filtration; and d) Chemical analysis. 
above the disk. To distribute the flow equally and reduce channeling, a second perforated disk was placed above the IE material. The total bed depth of the zeolite was $71.0 \mathrm{~mm}$, which resulted in an empty bed volume of $46.1 \mathrm{~mL}$. Flow control was accomplished by placing a clamp on the rubber tubing used for the column effluent. The feed to the column was introduced into the column by a $2.0 \mathrm{~L}$ plastic reservoir, which helped ensure a constant head above the IE material. This was a gravity flow system, where the water level within the column was always above the media, ensuring an adequate contact time.

A flow rate of approximately $29 \mathrm{~mL} / \mathrm{min}$ was maintained for the loading cycles and effluent was collected after various predetermined intervals for chemical analysis. The column was then regenerated using the regeneration solution that was identified as the best in the batch loading/regeneration tests; the regenerant flowrate was approximately $1 \mathrm{~mL} / \mathrm{min}$.

During the first experiment, the column was loaded with the EIMWW, run until exhaustion and subsequently regenerated. In the second run, the regenerated SIR-600 zeolite was again loaded with the EIMWW until a breakthrough concentration of $0.55 \mathrm{meq}$ TA/L $\left(10 \mathrm{mg} / \mathrm{L}\right.$ as $\left.\mathrm{NH}_{4}\right)$ was reached. The same media was regenerated and used to conduct a third column run with the $3.87 \mathrm{meq}$ TA/L $(70 \mathrm{mg} / \mathrm{L}$ as $\mathrm{NH}_{4}$ ) synthetic wastewater as feed to quantify the impact of the competition; this column was once again run until a breakthrough concentration of 0.55 meq TA/L.

To compare the performance of the column with regard to potassium, calcium and $\mathrm{TA}$, the respective capacities were calculated using a simplified numerical integration of the mass of the species removed [32]:

$\mathrm{q}_{\text {column }}=\frac{1}{\mathrm{M}} \sum \mathrm{Q}\left(\mathrm{C}_{\text {feed }}-\mathrm{C}_{\text {eff }}\right) \Delta \mathrm{t}$

where $\mathrm{q}_{\text {column }}$ is the capacity for a given species that has been achieved by the IE material within a column at a given time (meq contaminant/g ion exchange media); $\mathrm{Q}$ is the flow rate for a given time interval $(\mathrm{L} / \mathrm{min}) ; \mathrm{M}$ is the mass of IE material present in the column ( $\mathrm{g}$ ); $\mathrm{C}_{\text {feed }}$ and $\mathrm{C}_{\text {eff }}$ are the influent and influent pollutant concentrations respectively $(\mathrm{meq} / \mathrm{L})$; and $\Delta t$ is the given time step (min).

\section{Results and Discussion}

\subsection{EIMWW Characteristics}

To characterize EIMWW, it was analyzed for TA, $\mathrm{K}, \mathrm{Ca}$, and $\mathrm{pH}$ in-house and by ICP at the University of Ottawa's Advanced Research Centre and confirmed at a commercial lab. The results are presented in Table 1. EIMWW had a $\mathrm{pH}$ of approximately 5.7 and the main cations were TA (3.87 meq/L), Ca $(3.9 \mathrm{meq} / \mathrm{L}), \mathrm{K}(2.85 \mathrm{meq} / \mathrm{L})$, and sodium $(11.8 \mathrm{meq} / \mathrm{L})$. The main anions were sulfate and bicarbonate. So EIMWW had approximately the same concentration of $\mathrm{Ca}$ and TA in meq/L and they were $35 \%$ higher than the $\mathrm{K}$ concentration. Given the general selectivity order of clinoptilolite presented in the introduction, the ions that will impact TA removal the most will be $\mathrm{K}$, and $\mathrm{Ca}$.

\subsection{Batch Loading and Regeneration Studies}

The first phase of this study focused on the effects of repeated loading of natural and modified SIR-600

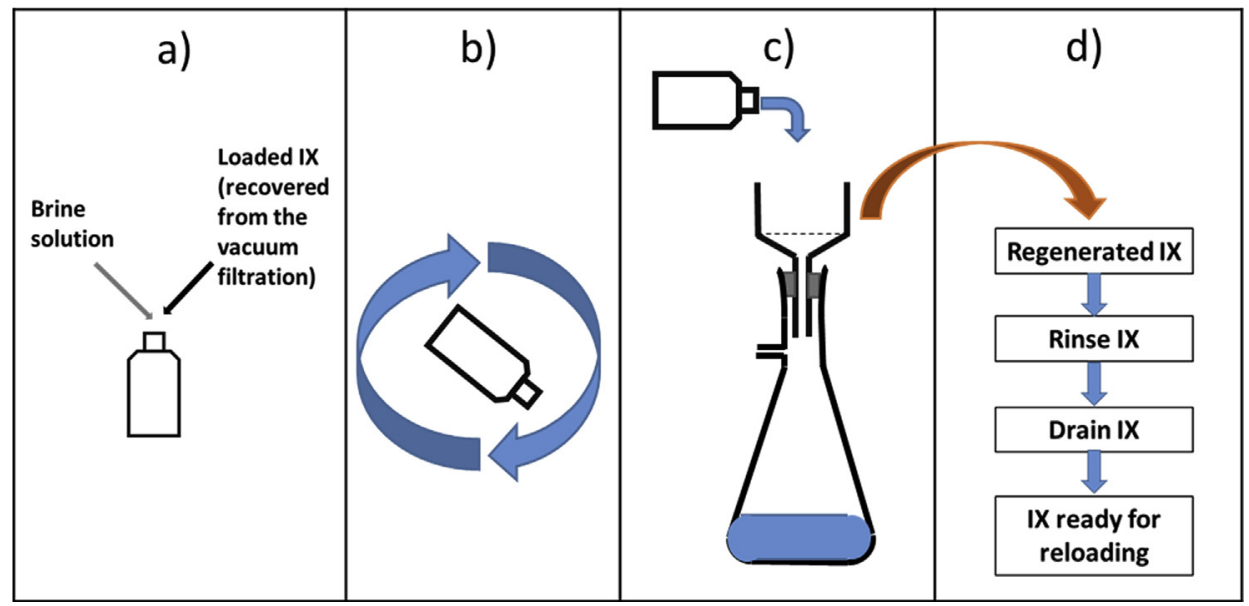

Fig. 2. Schematic of the IX Material Batch Regeneration Procedure: (a) Bottle preparation with a brine solution; $b$ ) 48 hr equilibration while mixing in tumbler; c) Separation by vacuum filtration; and d) Preparation of IX material for reuse. 


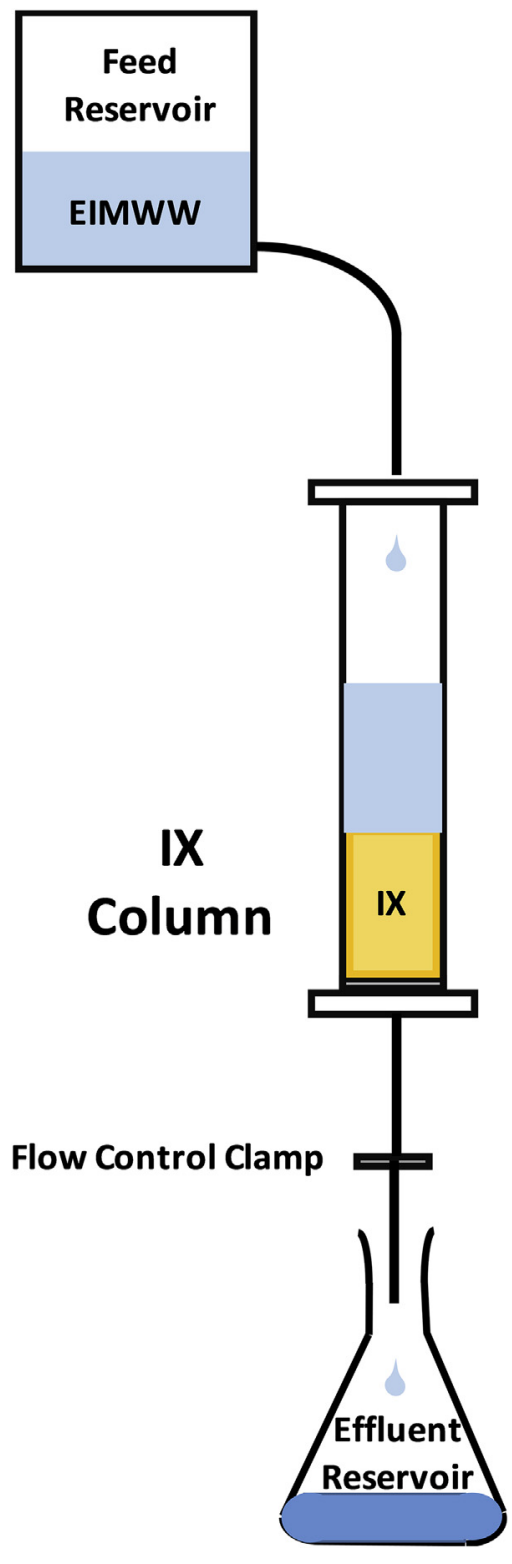

Fig. 3. Schematic of the Column Apparatus.

zeolites with real EIMWW. Subsequent regeneration cycles were performed with various regeneration fluids to establish the effects of regenerant concentration and composition, as well as to determine the long-term performance of both materials.

The impact of the multiple EIMWW loading and regeneration cycles on the average TA exchange capacities for SIR-600 and the clinoptilolite are shown in Figs. 4 and 5 respectively. The error bars represent one standard deviation. For SIR-600, the two $\mathrm{KCl}$ regenerations solutions (Fig. 4) show a decrease in TA exchange capacities of approximately $0.1 \mathrm{meq} \mathrm{TA} / \mathrm{g}$ over three cycles, or approximately $25 \%$. These reductions in TA capacity were likely caused by a higher affinity for potassium and by the greater quantities of $\mathrm{K}^{+}$present after the $\mathrm{KCl}$ regeneration. This would lead to a higher portion of exchange sites occupied by $\mathrm{K}^{+}$. Due to lower TA uptake capacities for both IE materials, the regenerations using $\mathrm{KCl}$ based solutions did not seem promising and were abandoned after 3 cycles and only the $\mathrm{NaCl}$ based regenerants were tested for a $4^{\text {th }}$ cycle.

Previous studies $[18,24]$ suggest that a noticeable increase in exchange capacity is possible due to the conditioning of the ion-exchange as it undergoes regeneration cycles. This was the case for the $5 \%$ and $10 \% \mathrm{NaCl}$ regenerated IE, but not for the $2.5 \%$ $\mathrm{NaCl}$ regeneration. The $2.5 \% \mathrm{NaCl}$ regenerant did not contain enough sodium to increase the SIR600 TA exchange capacities in later cycles, which remained between $0.34-0.38 \mathrm{meq} \mathrm{TA} / \mathrm{g}$ over the four cycles. The $10 \% \mathrm{NaCl}$ had the highest capacities ranging from $0.38-0.50 \mathrm{meq} \mathrm{TA} / \mathrm{g}$ over the four cycles for SIR-600.

Fig. 5 presents the repeated averaged TA uptake capacities for the same regeneration solutions applied to the clinoptilolite. The clinoptilolite regeneration cycles featured similar trends as those presented for the SIR-600 but had greater variability. By comparing Figs. 4 and 5 it was immediately evident that the SIR-600 results were more consistent. Not only are the error bars for the SIR600 smaller in most cases, but the clinoptilolite's results are more variable. This was attributed to clinoptilolite's natural origins that give it a lower product consistency than the manufactured SIR- 600 . As can be seen in Figs. 4 and 5, SIR-600 and clinoptilolite had lower TA capacities when regenerated with $2.5 \% \mathrm{NaCl}$ solutions compared to 5 and $10 \% \mathrm{NaCl}$ solutions.

The impact of the multiple EIMWW and regeneration cycles with $10 \% \mathrm{NaCl}$ on the calcium exchange capacity is shown in Fig. 6 . The first loading cycle yielded a negative $\mathrm{Ca}^{2+}$ exchange capacity for the clinoptilolite. This indicated that calcium was initially present as an exchangeable cation, and some $\mathrm{Ca}^{2+}$ leached during the first loading cycle. It has been reported in literature that clinoptilolite may initially contain several counter-ions, including calcium and potassium $[7,21,33]$. Furthermore, the clinoptilolite featured a larger affinity for calcium than the SIR-600, as the second through fourth loadings resulted in larger calcium uptake capacities than the SIR-600. The clinoptilolite had an equilibrium capacity of $0.16 \pm 0.01 \mathrm{meq} \mathrm{Ca}^{2} / \mathrm{g}$. The SIR-600 featured a slight increase in capacity with loading cycles and stabilized at approximately $0.12 \mathrm{meq} \mathrm{Ca}^{2}$ I g. The lower SIR-600 affinity for $\mathrm{Ca}^{2}$ is likely linked 
Table 1. List of Species and Corresponding Concentrations Present in the EIMWW.

\begin{tabular}{lll}
\hline Species & Concentration $(\mathrm{mg} / \mathrm{L})$ & Concentration $(\mathrm{meq} / \mathrm{L})$ \\
\hline $\mathrm{Cs}$ & N.D. & N.D. \\
$\mathrm{K}$ & 111.5 & 2.85 \\
$\mathrm{TA}$ & 70.0 & 3.87 \\
$\mathrm{Ca}^{2+}$ & 78.05 & 3.90 \\
$\mathrm{Fe}$ & 0.70 & 0.04 \\
$\mathrm{Al}$ & 0.08 & 0.01 \\
$\mathrm{Mg}$ & 12.67 & 1.04 \\
$\mathrm{Si}$ & 3.56 & 0.51 \\
$\mathrm{~B}$ & 0.07 & 0.02 \\
$\mathrm{Ca}$ & 78.05 & 3.90 \\
$\mathrm{Sr}$ & 2.10 & 0.05 \\
$\mathrm{Na}$ & 270.29 & 11.76 \\
$\mathrm{~K}$ & 111.5 & 2.85 \\
$\mathrm{SO}_{4}$ & 1050.0 & 21.86 \\
$\mathrm{HCO}_{3}$ & 300.0 & 4.92
\end{tabular}

to this media's somewhat higher TA exchange capacities shown in Fig. 4.

The potassium exchange capacities over four loading cycles with $10 \% \mathrm{NaCl}$ as the regeneration solution are presented in Fig. 7. Both IE materials experienced increased $\mathrm{K}^{+}$loadings following the first exchange cycle. The leaching of preloaded calcium is believed to be partially responsible $[20,21]$ for the lower first $\mathrm{K}^{+}$loadings. The increase in potassium capacities during the second and subsequent cycles could be attributed to the leaching of preloaded potassium. Prior to the first test, the zeolites were only rinsed with distilled water to remove any dirt or impurities, therefore the second factor which may have caused the increase of $\mathrm{K}^{+}$ uptake capacities was the conditioning of the zeolites. The clinoptilolite respectively leached $0.2,0.24$ and 0.32 meq $\mathrm{K}^{+}$for the $2.5,5$ and $10 \%$ regenerants whereas the SIR-600 leached $0.26,0.27$ and 0.36 meq $\mathrm{K}^{+}$. Several studies have stated that repeated loading/regeneration cycles can increase the capacity of a material, by creating a uniformity of counter-ions $[14,18,24]$.

The structure of zeolites plays an important role in defining the selectivity of materials. It has been stated that zeolitic structures containing high Si to Al ratio, in fact, have a higher selectivity towards lower charge density elements [34]. Clinoptilolite is one such material. According to the supplier[28], the clinoptilolite used in this study had a $\mathrm{Si} / \mathrm{Al}$ ratio of 22.4, which is much larger than typical clinoptilolites which have ratios ranging from 2.7 to 5.7 [34]. Thus, the higher $\mathrm{Si} / \mathrm{Al}$ ratio in this study, may explain the higher capacities for potassium. In contrast, the SIR600 featured a smaller calcium capacity than the clinoptilolite and a higher potassium capacity relative to its calcium (a high charge density cation) capacity.

Table 2 summarized the averaged calcium, potassium and TA capacities for the $4^{\text {th }}$ exchange cycle for $5 \%$ and $10 \% \mathrm{NaCl}$ regenerations. As the potassium based regenerants and the $2.5 \% \mathrm{NaCl}$ regenerant resulted in lower TA capacities, they were omitted from Table 2. The main findings of Table 2 are as follows. First, increasing the concentration of regenerant from $5 \%$ to $10 \%$ did not result in a significant increase of the TA exchange capacity of both materials. For clinoptilolite the final capacities were $0.30 \pm 0.02 \mathrm{meq} \mathrm{TA} / \mathrm{g}$ and $0.34 \pm 0.02 \mathrm{meq} \mathrm{TA} / \mathrm{g}$, while for SIR-600 they were $0.44 \pm 0.03 \mathrm{meq} \mathrm{TA} / \mathrm{g}$ and $0.46 \pm 0.01 \mathrm{meq} \mathrm{TA} / \mathrm{g}$, respectively. Second, for the $10 \% \mathrm{NaCl}$ regenerant the SIR-600 media had resulted $35 \%$ higher TA exchange capacities from EIMWW than clinoptilolite $(0.46 \pm 0.01 \mathrm{meq} \mathrm{TA} / \mathrm{g}$ versus $0.34 \pm 0.02 \mathrm{meq} T A / g$ ), thus it was selected for the subsequent column studies. Third, for both materials the average capacities indicated a preference for potassium over TA. The literature for the selectivity of zeolites such as clinoptilolite $[26,33]$ tends to be in agreement, suggesting that there is a defined order of selectivity, with a slight preferential exchange of $\mathrm{K}^{+}$over TA. Clinoptilolite's average potassium exchange capacity was higher than its TA exchange capacity for both the $5 \% \mathrm{NaCl}$ and the $10 \% \mathrm{NaCl}, 20 \%$ and $16.7 \%$ higher, respectively. However, for the $10 \% \mathrm{NaCl}$-clinoptilolite experiments the $95 \%$ confidence limits of the $\mathrm{K}^{+}$and TA loadings overlap, therefore, the difference is not statistically significant. In contrast, for SIR-600 with $10 \% \mathrm{NaCl}$ regeneration the $95 \%$ confidence limits of the $\mathrm{K}^{+}$and TA uptake capacities do not overlap so they are significantly different; while for SIR-600 with $5 \% \mathrm{NaCl}$ regeneration the $\mathrm{K}^{+}$and TA loadings are not statistically different. Thus, for EIMWW the media tested have a slight preference of $\mathrm{K}^{+}$over $\mathrm{NH}_{4}^{+}$.

The $\mathrm{pH}$ of all regeneration solutions was raised to a value between 9.5 and 10, and monitored before and after contact with IE materials (i.e., the regeneration process). It was noted that after contact with the ion exchange material the $\mathrm{pH}$ decreased by a similar amount for both IE materials, approximately 1-1.5 $\mathrm{pH}$ units. All regeneration cycles featured similar $\mathrm{pH}$ reductions regardless of the regenerant used. This reduction in $\mathrm{pH}$ was 


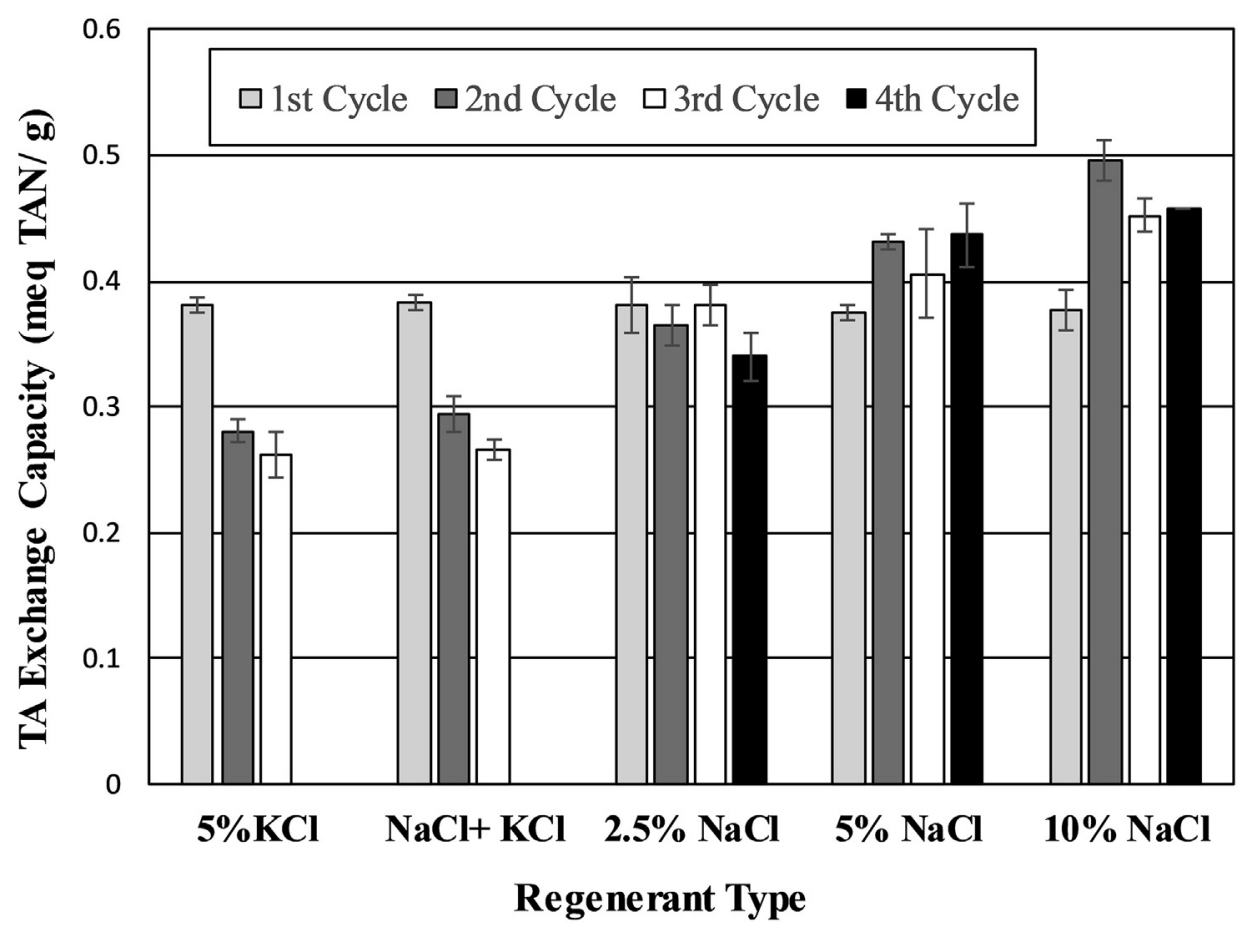

Fig. 4. Impact of Regenerant Type on the SIR-600's TAN Capacity in the Multiple Batch Tests.

attributed to the elution of $\mathrm{NH}_{4}^{+}$during the regeneration step which caused the shift in the TA concentration from ammonium $\left(\mathrm{NH}_{4}^{+}\right)$to ammonia $\left(\mathrm{NH}_{3}\right)$ due to the elevated $\mathrm{pH}$. The shift is described by the equation

$\mathrm{NH}_{4}^{+} \leftrightarrow \mathrm{NH}_{3}+\mathrm{H}^{+}$
The shift results in the generation of $\mathrm{H}^{+}$and a decrease in the $\mathrm{pH}$. Similar results have been reported elsewhere [5].

\subsection{Column Studies}

Full-scale IE applications generally consist of continuous flow column systems for practical

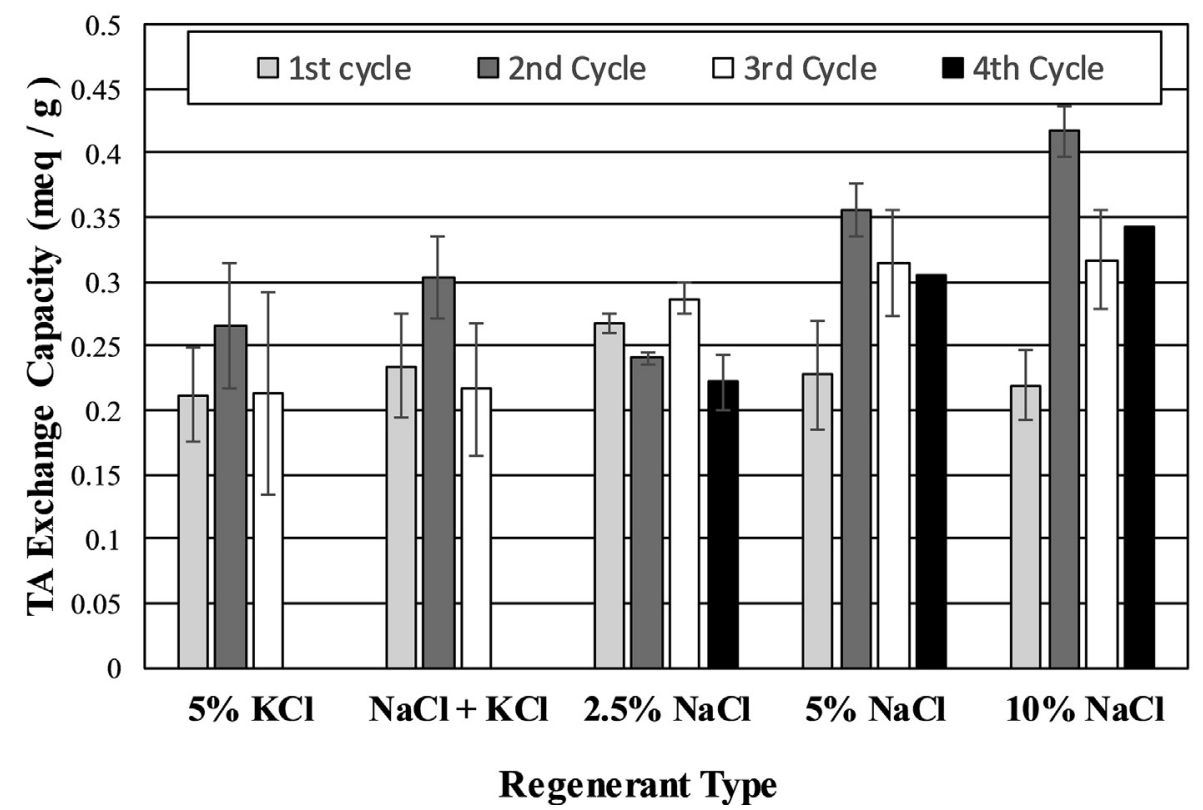

Fig. 5. Impact of Regenerant Type on the Clinoptilolite's TAN Capacity in the Multiple Batch Tests. 


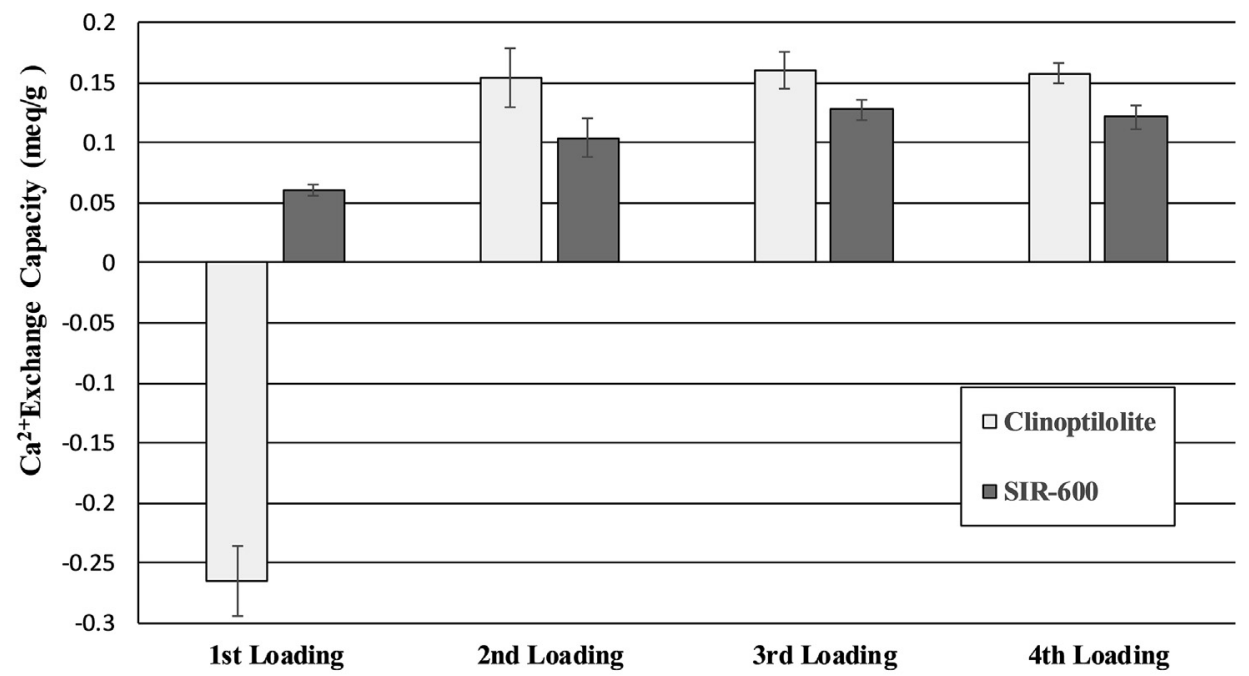

Fig.6. Successive Average Calcium Uptake Capacities in the Multiple Batch Tests with 10\% NaCl Regenerantion.

reasons as well as to maximize operational efficiency. Therefore, it was important to determine if the EIMWW could be treated in a column system, particularly because in these systems the contact times are only in the order of minutes and the kinetics of the exchange may impact the selectivity. A second goal of this column study was to quantify the reduction in TA capacity of a continuous IE column resulting from the presence of multiple competing species by comparing the performance when treating the EIMWW versus a synthetic TA solution. Based on the higher TA capacities and lower $\mathrm{Ca}^{2+}$ uptakes achieved from the batch regeneration studies, the SIR-600 modified zeolite was selected for the column studies.

Fig. 8 illustrates the first column run's effluent concentrations of TA versus the volume of water treated in terms of bed volumes (BV) using a flow rate of approximately $29 \pm 2 \mathrm{~mL} / \mathrm{min}$. This figure shows that $\mathrm{Ca}^{2+}$ broke through almost immediately and at approximately $30 \mathrm{BV}$ the media became saturated with $\mathrm{Ca}^{2+}\left(\right.$ i.e., $\mathrm{C}_{\text {eff }} / \mathrm{C}_{\text {feed }}=\sim 1 \mathrm{meq} / \mathrm{L}$ ). The effluent TA and $\mathrm{K}^{+}$concentrations were almost negligible up to that point, they increased significantly between 30 and $35 \mathrm{BV}$ and gradually thereafter. During this latter part of the run there was no $\mathrm{Ca}^{2+}$ removal (i.e., $\mathrm{C}_{\text {eff }}=\mathrm{C}_{\text {feed }}=4.17 \mathrm{meq} / \mathrm{L}$ ), the TA concentration increased gradually and the $\mathrm{K}^{+}$concentrations were consistently lower than those of TA. This reinforces the SIR-600 batch test results in Table 2, which demonstrated a preference for potassium and TA over calcium. The column run was stopped after treating $91 \mathrm{BV}$ of EIMWW, as the column was approaching saturation with repect to TA $\left(\mathrm{C}_{\text {eff }} / \mathrm{C}_{\text {feed }} \sim 0.85\right)$. At that time, the effluent potassium concentration was approximately $50 \%$ of the feed concentration, suggesting a higher ultimate potassium capacity. It is believed that this higher potassium capacity caused the TA exchange zone to move ahead of the potassium exchange front, resulting for a time in primarily single component TA ion-exchange in the portion of the column ahead of the potassium exchange front. It would seem that the potassium front begun to displace previously sorbed TA ions at $30 \mathrm{BV}$, where the TA effluent concentration became significantly higher than that of $\mathrm{K}^{+}$.

The resulting exchange capacities for calcium, potassium and TA (Fig. 9) were calculated using the Fig. 8 data and equation (2). This figure shows that SIR-600 had a slight preference for TA over potassium, up until approximately 90 BV of EIMWW treated. This preference for TA may be due to the lower $\mathrm{K}^{+}$feed concentration $(2.75$ versus $3.75 \mathrm{meq} / \mathrm{L})$. The TA and $\mathrm{K}^{+}$capacities are consistent with the batch test results presented in Table 2, which reported similar capacities for potassium and TA. The horizontal dotted/dashed lines in Fig. 9 represents the $\mathrm{K}^{+}$, TA and $\mathrm{Ca}^{2+}$ exchange capacities obtained for batch studies treating the same source of EIMWW. This dotted line (TA batch) helps illustrate that the TA uptake of the continuous flow column system is approximately $48 \%$ smaller than of the batch set-up ( 0.24 meq TA/g vs 0.46 meq TA/ $\mathrm{g})$. It is possible that this was due to a drastic reduction in contact times; the batch tests had 


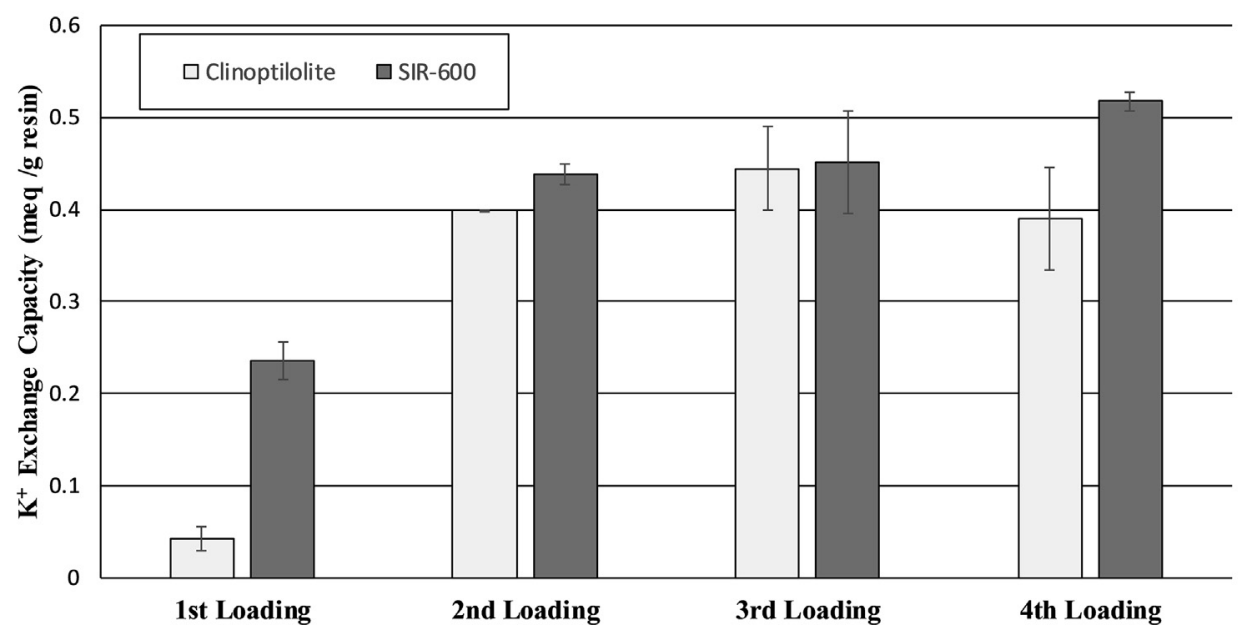

Fig.7. Successive Potassium Uptake Capacities in the Batch Tests with 10\% NaCl Regeneration.

a contact time of $24 \mathrm{hrs}$, whereas during lab-scale column test the contact time was 1.6 minutes. The differences between the two types of tests are more likely explained by the nature of the tests. During the batch tests there was a limited mass of the stronger sorbing species (i.e., $\mathrm{K}^{+}$) which limited the extent of the reduction in the exchange capacity exhibited for TA, while in the column system, the feed continuously introduced additional mass of the $\mathrm{K}^{+}$and resulted in even greater competitive exchange and a reduction in the TA capacity. The top dashed grey line (Batch $\mathrm{K}$ ) shows that the $\mathrm{K}$ loadings achieved in the column tests were significantly lower than those achieved in the batch tests. If the column would had been operated longer, the $\mathrm{K}^{+}$ loadings would had increased further possibly reaching the levels observed during the batch tests. The lower column $\mathrm{K}^{+}$loadings illustrate the

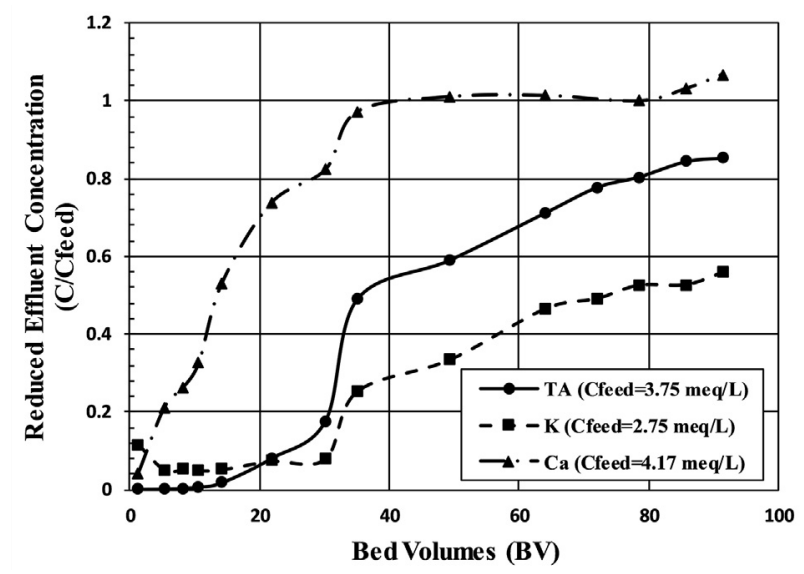

Fig.8. Breakthrough Curves for $\mathrm{Ca}^{2+}, \mathrm{K}^{+}$and TA in the Treatment of EIMWWISIR-600 Column Run. dynamic nature of column tests. During the column test the $\mathrm{Ca}^{2+}$ loading reached a plateau level after 30 $\mathrm{BV}$ of water treated, i.e., the media is saturated with $\mathrm{Ca}^{2+}$. The $\mathrm{Ca}^{2+}$ loadings decreased very gradually thereafter, this decrease was expected as the SIR-600 media in the column is continuously exposed to more $\mathrm{K}^{+}$and TA ions. This is also the likely reason why the column capacities are significantly lower than that observed during the batch tests (i.e., the bottom dashed line in Fig. 9).

The column was regenerated several times with a $10 \% \mathrm{NaCl}$ solution. The column experiment was repeated with EIMWW, and for this second column run an effluent breakthrough concentration criterion of $0.55 \mathrm{meq}$ TA/L $(10 \mathrm{mg}$ TA/L) was used. This breakthrough concentration was selected as it is a potential effluent discharge criterion; the actual criteria is likely to depend on the degree of dilution upon discharge into a receiving water. This column run was followed by another regeneration and a third column run using a single solute TA

Table 2. Average of the $4^{\text {th }}$ Exchange Cycle Uptake Capacities of Clinoptilolite and SIR-600 for 5 and $10 \% \mathrm{NaCl}$ Regeneration ( \pm one SD).

\begin{tabular}{lll}
\hline Clinoptilolite & & \\
\hline Regenerant & $5 \% \mathrm{NaCl}$ & $10 \% \mathrm{NaCl}$ \\
\hline $\mathrm{Ca}^{2+}$ Uptake Capacity (meq Ca & \\
$\mathrm{K}^{+}$Uptake Capacity (meq K$\left./ \mathrm{g}\right)$ & $0.14 \pm 0.02$ & $0.16 \pm 0.01$ \\
TA Uptake Capacity (meq TA/g) & $0.36 \pm 0.01$ & $0.39 \pm 0.06$ \\
\hline SIR-600 & $0.30 \pm 0.02$ & $0.34 \pm 0.02$ \\
\hline Regenerant & $5 \% \mathrm{NaCl}$ & $10 \% \mathrm{NaCl}$ \\
\hline $\mathrm{Ca}^{2+}$ Uptake Capacity (meq Ca & \\
$\mathrm{K}^{+}$Uptake Capacity (meq K$\left./ \mathrm{g}\right)$ & $0.13 \pm 0.06$ & $0.12 \pm 0.01$ \\
TA Uptake Capacity (meq TA/g) & $0.46 \pm 0.04$ & $0.52 \pm 0.01$ \\
\hline
\end{tabular}




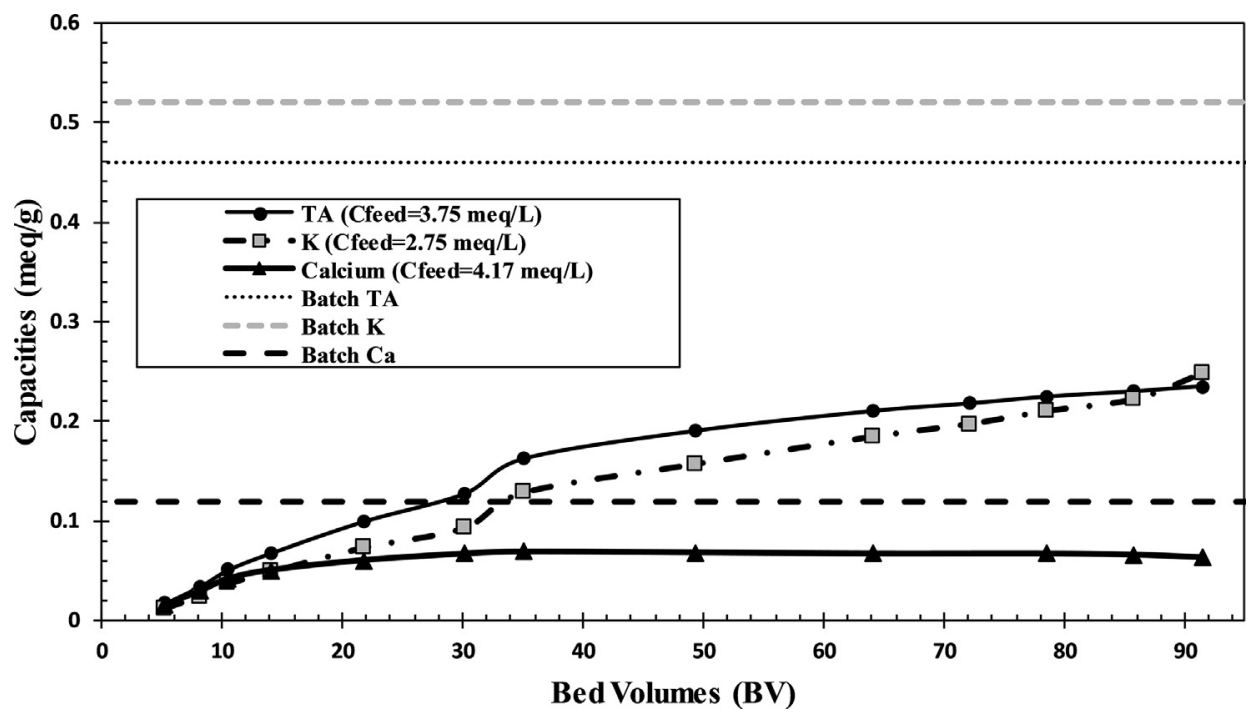

Fig.9. Contaminant Column Exchange Capacities for the First Column Run with EIMWW.

synthetic wastewater solution. The results of the second and third column runs are presented in Fig. 10 where the effluent TA concentration versus treated bed volumes for both wastewaters are compared, thus allowing to determine the extent to which competing ions affect the exchange process. The presence of competing ions resulted in a much earlier TA breakthrough than for the synthetic single component wastewater (50 BV versus $274 \mathrm{BV}$ ). When treating the EIMWW using the above breakthrough level, the column's IE material was only able to treat $18 \%$ of the volume of wastewater that it would treat when the feed was a single solute TA solution. These results clearly confirm that the feasibility of TA ion exchange applications need to be assessed with the wastewater in question and not a single solute TA solution. Furthermore, during the second column run the $0.55 \mathrm{meq}$ TA/L

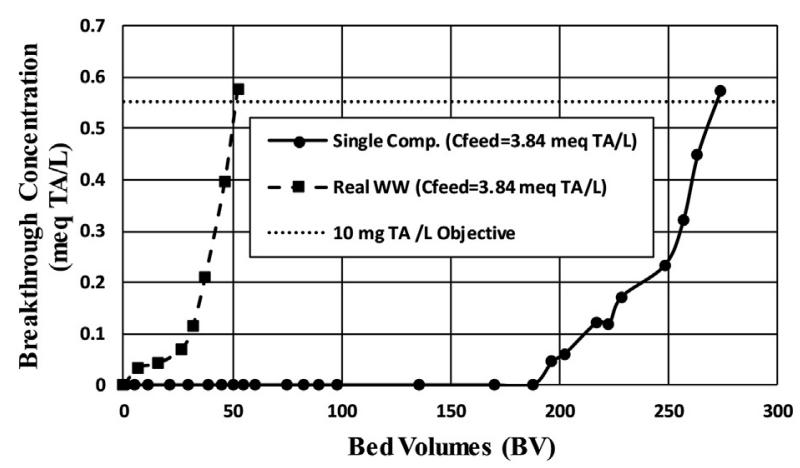

Fig.10. Breakthrough curve for TA for the Second EIMWW Column Run and the Single Component Wastewater Column Run. breakthrough level occurred at $\sim 50 \mathrm{BV}$, which is later than in the initial column run $(20 \mathrm{BV}$ in Fig. 8$)$. The smaller quantity of BV's treated prior to breakthrough is attributed to the lack of conditioning prior to the initial column run.

Using the data in Fig. 10 and equation (2), TA uptake capacities were obtained for both the single component synthetic wastewater and the second EIMWW run during the 0.55 meq TA/L breakthrough experiments (Fig. 11). When the TA capacities were considered during the first $50 \mathrm{BV}$, the synthetic wastewater's exchange capacities were nearly identical to the EIMWW TA capacities. This implies that the impact of competition had not yet taken effect. It is believed that exchange capacity for potassium was somewhat higher than that of TA, resulting in the potassium ion exchange front within

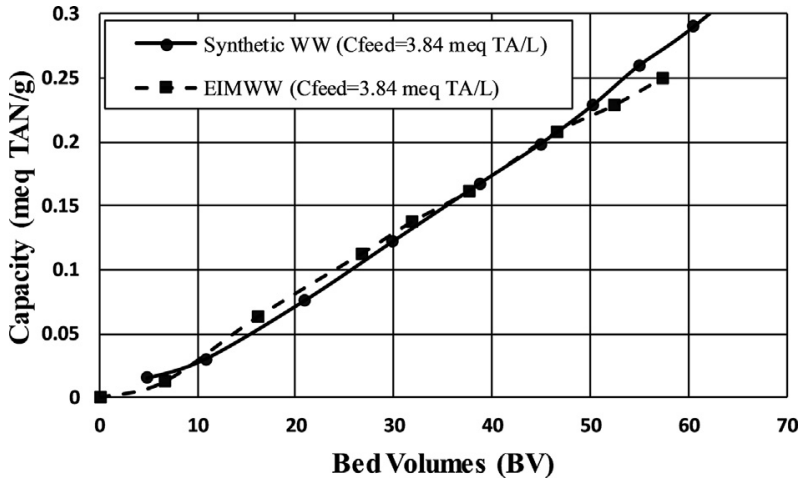

Fig.11. TA Column Capacities versus Bed Volumes Treated for the Second EIMWW Column Run and the Synthetic Wastewater Column Run. 
the IE bed to trail behind the TA ion exchange front. This could be in part due to the lower influent $\mathrm{K}^{+}$ concentration $(\sim 26 \%)$ which resulted slower relative loading rates.

In the treatment of the synthetic TA wastewater, the SIR-600 column treated 274 BV of wastewater (Fig. 10) before reaching the breakthrough concentration of $0.55 \mathrm{meq} T A / \mathrm{L}$, so it achieved a TA uptake of $1.19 \mathrm{meq} \mathrm{TA} / \mathrm{g}$. At the same breakthrough level, the column treating EIMWW only achieved $20 \%$ of this value $(0.24 \mathrm{meq} \mathrm{TA} / \mathrm{g})$. The potassium and calcium capacities were respectively $0.21 \mathrm{meq} \mathrm{K}^{+} / \mathrm{g}$ and $0.17 \mathrm{meq} \mathrm{Ca}^{2+} / \mathrm{g}$ for the second loading run. Thus, the column's $\mathrm{K}^{+}$uptake capacity at the breakthrough (i.e., non-saturation) was $23 \%$ higher than that of TA, while for the batch tests for the same sorbent-regenerant combination, the $\mathrm{K}^{+}$capacity was only $11.3 \%$ higher. This indicates that the dynamic conditions in the column further favour the exchange of $\mathrm{K}^{+}$over TA. At the TA breakthrough in the second column run, the summation of the loadings of the three species was a total of $0.62 \mathrm{meq} / \mathrm{g}$, approximately half of the total measured capacity for the synthetic wastewater (i.e., $1.19 \mathrm{meq} / \mathrm{g})$. The higher value for the synthetic wastewater was likely due to the greater than fivefold longer column run which permitted greater degree of ion exchange. Finally, the effluent $\mathrm{pH}$ was 6.14 so the $10 \mathrm{mg}$ TA/L breakthrough concentration corresponds to an unionized ammonia of $0.007 \mathrm{mg} \mathrm{N} / \mathrm{L}$, which is lower than the Canadian $\mathrm{NH}_{3}$ industrial effluent guideline [5].

It is also of note that for the breakthrough level of the second column run, the TA uptake by the SIR600 was approximately $0.23 \mathrm{meq} \mathrm{TA} / \mathrm{g}$, while the batch test loadings of SIR-600 regenerated with 5\% $\mathrm{KCl}$ achieved an uptake of $0.27 \mathrm{meq} \mathrm{TA} / \mathrm{g}$. The similar capacities probably arise from the fact that the $\mathrm{KCl}$ regenerated media contained substantial quantities of the main competing cation $\left(\mathrm{K}^{+}\right)$and was also exposed to a large mass of $\mathrm{K}^{+}$. Thus, using $\mathrm{K}^{+}$preloaded media may be useful as a simple estimator of EIMWW column TA removals. The similarities may be coincidental, so this needs to be verified.

\section{Conclusion}

Two zeolites, a natural clinoptilolite and a modified clinoptilolite (SIR-600) were evaluated for their regenerative abilities and long-term performance when removing TA from an explosive impacted mining wastewater. The batch exchange/regeneration/ion-exchange experiments showed that regenerating both zeolites using $\mathrm{KCl}$ solutions resulted in smaller TA uptake capacities from EIMWW compared to the $\mathrm{NaCl}$ solutions. The regeneration with the $5 \%$ and the $10 \% \mathrm{NaCl}$ solution resulted in the highest TA batch test uptakes, and the modified clinoptilolite had higher TA uptake from EIMWW than the clinoptilolite.

The removal of TA was greatly impacted by the presence of $\mathrm{K}^{+}$and $\mathrm{Ca}^{+2}$ as competing ions in EIMWW. The batch loading tests showed that both media had a slight preference for $\mathrm{K}^{+}$over TA. In the EIMWW column tests, TA broke through before potassium confirming that the media had a higher selectivity for potassium. The most dramatic demonstration of the competitive interactions by the other ions in EIMWW was that the same column was able to treat five times more volume of a single solute ammonia solution than EIMWW for the same $0.55 \mathrm{meq}$ TA/L breakthrough level. It is noteworthy that for the initial period of SIR-600 column treatment had nearly identical TA exchange capacities for both the EIMWW and the synthetic solution, which suggests that competition from various ions, including potassium had not yet taken effect and would only become prominent if the column was operated for a longer duration. This indicated that potassium exchange capacity is higher than TA capacity, resulting in a slower $\mathrm{K}^{+}$adsorption front and the increase in TA concentration around breakthrough was caused by the $\mathrm{K}^{+}$adsorption front catching up.

Because the regeneration with a $5 \% \mathrm{KCL}$ solution incorporates many $\mathrm{K}^{+}$ions into the media, the batch test loadings using $\mathrm{KCl}$ regenerated media may be a simple and reasonable estimator of the column TA capacities. This requires verification.

The current study was performed using an explosives impacted mining wastewater secured from a mine, and the ion exchange material performed well in our limited length studies. Longer term testing needs to be performed using different EIMWWs which may include other contaminants that may impact the life of the ion exchange material. It is envisioned that the ion exchange material may have to be replaced every year or two. Based on the current results the EIMWW treatment system is expected to consist of two ion exchange columns, one that is in operation while the other is off-line being regenerated with a $\mathrm{NaCl}$ solution or waiting to go back on-line. It is expected that ion exchange cycles will last at least six hours while the regeneration will be completed in about two hours. Alternative schemes to treat the regeneration solution to 
permit continuous reuse need to explored, however in the current study is concerned primarily on the TA removal.

\section{Ethical statement}

Authors state that the research was conducted according to ethical standards.

\section{Funding body}

Natural Sciences and Engineering Research Council of Canada's Engage program, grant number 505278-16.

\section{Conflict of interest}

None declared.

\section{Acknowledgements}

This project was made possible by the collaboration of Newterra, Inc. and the financial support from the Natural Sciences and Engineering Research Council of Canada's Engage program, grant number 505278-16.

\section{References}

[1] Jermakka J, Wendling L, Sohlberg E, Heinonen H, Vikman M. Potential Technologies for the Removal andRecovery of Nitrogen Compounds From Mine andQuarry Waters in Subarctic Conditions. Critical Reviews in Environmental Science andTechnology 2015;45:703-48. https:// doi/10.1080/10643389.2014.900238.

[2] Bailey BL, Smith LJD, Blowes DW, Ptacek CJ, Smith L, Sego DC. The Diavik Waste Rock Project: Persistence of contaminants fromblasting agents in waste rock effluent. Applied Geochemistry 2013;36:256-70. https://doi.org/ 10.1016/j.apgeochem.2015.10.010.

[3] Zaitsev G, Mettänen T, Langwaldt J. Removal of ammonium and nitrate from cold inorganic mine waterby fixed-bed biofilm reactors. Minerals Engineering 2008;21:10-5. https:// doi:10.1016/j.mineng.2007.08.014.

[4] Koren DW, Gould WD, Bédard P. Biological removal of ammonia and nitrate fromsimulated mine and mill effluents. Hydrometallurgy 2000;56_2000:127-44. https://doi.org/ 10.1016/S0304-386X(99)00088-2.

[5] EC-HC (Environment Canada and Health Canada). Priority Substances List Assessment - Ammonia in the Aquatic Environment. 2001. https://www.canada.ca/en/healthcanada/services/environmental-workplace-health/reportspublications/environmental-contaminants/canadianenvironmental-protection-act-1999-priority-substances-listassessment-report-ammonia-aquatic-environment.html.

[6] Jorgensen TC, Weatherley LR. Ammonia removal from wastewater by ion exchange in the presence of organic contaminants. Water Research 2003;37(8):1723-8. https:// doi/10.1016/S0043-1354(02)00571-7.

[7] Weatherley LR, Miladinovic ND. Comparison of the ion exchange uptake of ammonium ion onto New Zealand clinoptilolite and mordenite. Water Research 2004;38(20): 4305-12. https://doi:10.1016/j.watres.2004.08.026.

[8] Almutairi A, Weatherley LR. Intensification of ammonia removal from waste water in biologically active zeolitic ion exchange columns. J. of Environmental Management 2015;160:128-38. https://doi:10.1016/j.jenvman.2015.05.033.

[9] Carrera J, Baeza JA, Vicent T, Lafuente J. Biological nitrogen removal of high-strength ammonium industrial wastewater with two-sludge system. Water Research 2003;37(17): 4211-21. https://doi/10.1016/S0043-1354(03)00338-5.

[10] Halim AA, Aziz HA, Johari MAM, Ariffin KS. Comparison study of ammonia and COD adsorption on zeolite, activated carbon and composite materials in landfill leachate treatment. Desalination 2010;262(1):31-5. https://doi.org/10.1016/ j.desal.2010.05.036.

[11] Lee S-M, Jung J-Y, Chung Y-C. Measurement of ammonia inhibition of microbial activity in biological wastewater treatment process using dehydrogenase assay. Biotechnology Letters 2000;22(12):991-4. https://doi.org/10.1023/A: 1005637203643.

[12] Halling-Sørensen B, Jorgensen SE. Removal of nitrogen compounds from wastewater. Amsterdam: Elsevier; 1993. 1993.

[13] Ding Y, Sartaj M. Optimization of ammonia removal by ionexchange resin using response surface methodology. Int. J. Environmental Science \& Technology 2016;13(4):985-94. https://doi/10.1007/s13762-016-0939-x.

[14] Hedström A, Rastas Amofah L. Adsorption and desorption of ammonium by clinoptilolite adsorbent in municipal wastewater treatment systems. J. Environmental Engineering Science 2008;7(1):53-61. https://doi.org/10.1139/S07-029.

[15] Malovanyy A, Sakalova H, Yatchyshyn Y, Plaza E, Malovanyy M. Concentration of ammonium from municipalwastewater using ion exchange process. Desalination 2013;329:93-102. https://doi.org/10.1016/ j.desal.2013.09.009.

[16] Dong S, Sartaj M. Statistical analysis of thermal and nonthermal effects of sequential microwave/aeration process for the removal of ammonia from aqueous solution. Desalination \&Water Treatment 2016;57(42):20005-15. https:// doi.org/10.1016/j.jece.2015.10.029.

[17] Huang J, Kankanamge NR, Chow C, Welsh DT, Li T, Teasdale PR. Removing ammonium from water and wastewater using cost-effective adsorbents: A review. J. of Environmental Science 2018;63:174-97. https://doi.org/10.1016/ j.jes.2017.09.009.

[18] Klieve JR, Semmens MJ. An evaluation of pretreated natural zeolites for ammonium removal. Water Research 1980;14(2): $161-8$.

[19] Hlavay J, Vigh GY, Olaszi V, Inczédy J. Investigations on natural Hungarian zeolite for ammonia removal. Water Research 1982;16(4):417-20. https://doi.org/10.1016/00431354(82)90165-8.

[20] Guo X, Zeng L, L, Li X, Park H-S. Ammonium and potassium removal for anaerobically digested wastewater using natural clinoptilolite followed by membrane pretreatment. J. Hazardous Materials 2008;151(1):125-33. https://doi.org/ 10.1016/j.jhazmat.2007.05.066.

[21] Montégut G, Michelin L, Brendlé J, Lebeau B, Patarin J. Ammonium and potassium removal from swine liquid manure using clinoptilolite, chabazite and faujasite zeolites. J. Environmental Management 2016;167:147-55. https:// doi.org/10.1016/j.jenvman.2015.11.027.

[22] Ding Y, Sartaj M. Statistical analysis and optimization of ammonia removal from aqueous solution by zeolite using factorial design and response surface methodology. J. Environmental Chemical Engineering 2015;3(2):807-14. https://doi.org/10.1016/j.jece.2015.03.025.

[23] Ames LL. The cation sieve properties of clinoptilolite. American Mineralogist 1960;45(5-6):689-700.

[24] Leyva-Ramos R, Aguilar-Armenta G, GonzalezGutierrez LV, Mendoza-Barron J. Ammonia exchange on clinoptilolite from mineral deposits located in Mexico, $J$. Chemical Technolology \& Biotechnology 2004;79(6):651-7. https://doi.org/10.1002/jctb.1035.

[25] Chen JP, Chua M-L, Zhang B. Effects of competitive ions, humic acid, and $\mathrm{pH}$ on removal of ammonium and 
phosphorous from the synthetic industrial effluent by ion exchange resins. Waste Management 2002;22(2002):711-9. https://doi.org/10.1016/S0956-053X(02)00051-X.

[26] Guo X, Zeng L, Jin X. Advanced regeneration and fixed-bed study of ammonium and potassium removal from anaerobic digested wastewater by natural zeolite. J. Environmental Science 2013;25(5):954-61. https://doi.org/10.1016/S10010742(12)60115-6.

[27] Casadellà A, Kuntke P, Schaetzle O, Loos K. Clinoptilolitebased mixed matrix membranes for the selective recovery of potassium and ammonium. Water Research 2016;90(1): 62-70. https://doi.org/10.1016/j.watres.2015.12.017.

[28] The Seed Supply. Granular Zeolite [Online]. Available: https://theseedsupply.com/products/granular-zeolite. [Accessed 20 April 2017].

[29] ResinTechInc. Resintech SIR-600. [Online]. Available: https://www.resintech.com/rks_images/shopcart/pdf_specs_ 90253.pdf; 2017 [Accessed: 26-Jun-2017].

[30] Chartrand ZG. The selective ion-exchange removal of ammonia from mining wastewater. MASc Thesis. Canada:
Dept. of Civil Engineering,Université d'Ottawa/University of Ottawa; 2018.

[31] APHA (American Public Health Association). Standard methods for the examination of water and waste water, 21st edn. Washington, DC. 2005. 2005.

[32] Inglezakis VJ. In: S.G.Poulopoulos, S (Online Service, S.Poulopoulos, editors. Adsorption and ion exchange, Chapter 4 in Adsorption, ion exchange and catalysis design of operations and environmental applications. 1st ed. 2006. https:// doi.org/10.1016/B978-0-444-52783-7.X5000-9. Amsterdam: Amsterdam, 2006.

[33] Jama MA, Yücel H. Equilibrium studies of sodium-ammonium, potassium-ammonium, and calcium-ammonium exchanges on clinoptilolite zeolite. Separation Science \& Technology 1989;24(15):1393-416. https://doi.org/10.1080/ 01496398908050659.

[34] Margeta K, Zabukovec Logar N, Siljeg M, Farkas A. Natural zeolites in water treatment - how effective is their use. In: Elshorbagy W, Chowdhury RK, editors. Water Treatment. Rijeka: IntechOpen; 2013. p. 81-112. https://doi.org/10.5772/ 50738 . 